\title{
Antineutrophil Cytoplasmic Autoantibody in the Absence of Wegener's Granulomatosis or Microscopic Polyangitis: Implications for the Surgical Pathologist
}

\author{
Anthony A. Gal, M.D., Alvaro Velasquez, M.D. \\ Departments of Pathology and Laboratory Medicine (AAG) and Division of Critical Care and Respiratory \\ Medicine (AV), Emory University School of Medicine, Atlanta, Georgia
}

Antineutrophil cytoplasmic antibodies (ANCA) are useful serologic markers for the diagnosis and management of patients with Wegener's granulomatosis (WG) and microscopic polyangiitis (MPA). However, problems in diagnosis and classification may occur when patients with other disorders develop ANCA. A 7-year review (1993-1999) disclosed 247 patients whose sera tested positively for ANCA by an indirect immunofluorescence method: 166 patients for cytoplasmic-ANCA (C-ANCA) and 81 patients for perinuclear-ANCA (P-ANCA) Twenty-seven patients had active pulmonary disease and underwent openlung biopsy or transbronchial biopsy. Eight patients (30\%) had a disease other than WG or MPA, and their clinical, pathological, and serological findings were reviewed. The patients, all women, ranged in age from 28 to 77 years (median, $37 \mathrm{y}$ ). Dyspnea ( $n$ $=6)$, cough $(n=6)$, chest pain $(n=2)$, and/or hemoptysis $(n=2)$ were present. The duration of symptoms lasted from 3 weeks to 6 years (median, 6 mo). ANCA titers were C-ANCA ( $n=4$; range, $1: 40$ 1280 ) or P-ANCA ( $n=4$; range, $1: 40-640$ ). The lung biopsies disclosed nonspecific interstitial pneumonia $(n=4)$, bronchiolitis obliterans organizing pneumonia $(n=1)$, diffuse alveolar damage $(n=1)$, organizing diffuse alveolar hemorrhage without capillaritis $(n=1)$, and necrotic granuloma $(n=1)$. No cases showed characteristic histology for WG or MPA. The final diagnoses were various connective tissue disorders $(n=5)$, chronic hypersensitivity pneumonia ( $n=1)$, postinfectious bronchitis/bronchiectasis $(n=1)$, and ulcerative colitis-related lung disease $(n=1)$. Surgical pathologists should be

Copyright (C) 2002 by The United States and Canadian Academy of Pathology, Inc.

VOL. 15, NO. 3, P. 197, 2002 Printed in the U.S.A.

Date of acceptance: November 19, 2001

Presented at the 89th Annual Meeting of the United States and Canadian Academy of Pathology, New Orleans, Louisiana, March 2000.

Address reprint requests to: Anthony A. Gal, M.D., Department of Pathology and Laboratory Medicine, Emory University Hospital, H-171, 1364 Clifton Road, N.E., Atlanta, GA 30322; e-mail: agal@emory.edu; fax: 404-712-4754.

aware that significantly elevated ANCA titers may be associated with diverse forms of pulmonary disease. ANCA positivity alone, in the absence of appropriate clinical or pathologic findings, should not be used to substantiate a diagnosis of WG or MPA.

KEY WORDS: Antineutrophil cytoplasmic antibodies, Microscopic polyangiitis, Vasculitis, Wegener's granulomatosis.

Mod Pathol 2002;15(3):197-204

Since the initial discovery by Davis et al. (1) of antineutrophil cytoplasmic antibodies (ANCA) in 1982, ANCA have become useful serological markers for the evaluation of systemic vasculitic disorders. The pulmonary diseases that are most frequently associated with ANCA include Wegener's granulomatosis (WG), microscopic polyangiitis (MPA), Churg Strauss syndrome, and other disorders (2-5). Elevated ANCA titers particularly occur during disease exacerbation but may be low or absent in remission $(3,6,7)$.

By indirect immunofluorescence (IIF), two wellrecognized staining patterns of ANCA tend to show associations with specific diseases $(7,8)$. In active WG, the majority of ANCA demonstrate a cytoplasmic pattern (C-ANCA) on IIF tests, although 5-20\% of ANCA may exhibit a perinuclear pattern (PANCA; 4). Enzyme-linked immunosorbent assays (ELISA) detect specific antigens directed to proteinase-3, which is a $29-\mathrm{kD}$ a serine proteinase in neutrophil primary granules $(9,10)$. In MPA, ANCA are present in $\leq 80 \%$ of sera, and the staining pattern tends to be perinuclear (P-ANCA; 4). ELISA assays in P-ANCA+ sera detect myeloperoxidase but occasionally identify other antigens $(2-5,11)$.

Although ANCA have become useful serological markers for diagnosis and disease monitoring, false-positive and false-negative ANCA occur for a variety of reasons (12-14). During a review of ANCA-positive patients who underwent lung biopsies at our institution, we identified a group of these 
patients who did not have a systemic vasculitic syndrome. In this report, we present the lung biopsy findings in a group of ANCA-positive patients who lacked clinical, serological, and pathological criteria for WG or MPA. Moreover, we would like to review some reasons why ANCA occurs in other disorders and propose guidelines for surgical pathologists who may be confronted with this problematic situation.

\section{MATERIALS AND METHODS}

A retrospective review was performed of ANCA testing from 1993 to 1999 at Emory University Hospital. The majority of patients were evaluated for active renal disease or vasculitic syndromes. There were 247 patients whose sera tested positively for ANCA by an IIF test (ANCA-IIF; Inova Diagnostics, San Diego, CA). There were 166 patients whose sera were C-ANCA+ and 81 patients whose sera were P-ANCA +. If the IIF demonstrated a P-ANCA pattern, differential fixation with formalin was used to discriminate between P-ANCA and antinuclear antibodies (15). ELISAs for ANCA were performed only if specifically ordered by the referring clinician.

All ANCA-IIF+ patients underwent a retrospective review of anatomical pathology records. An open-lung ( $n=26)$ or transbronchial $(n=1)$ biopsy was performed in 27 patients. Using pathological criteria for WG or MPA proposed by the Chapel Hill Consensus Conference (16), 19 patients had pathologic findings of WG (necrotizing granulomatous inflammation with vasculitis and/or alveolar hemorrhage with capillaritis) or MPA (alveolar hemorrhage with capillaritis) in their biopsies. The patients with vasculitis were excluded from this study.

Eight patients with open-lung biopsies who lacked clinical and pathologic criteria of WG or MPA formed the basis of this study. An additional review was undertaken of relevant clinical, radiological, and laboratory data including microbiological cultures and other serological tests. Follow-up information was obtained in all patients.

\section{RESULTS}

All patients in this study were women, ranging in age from 28 to 77 years, with a median of 37 years. At presentation the pulmonary findings included dyspnea $(n=6)$, cough $(n=6)$, chest pain $(n=2)$, and hemoptysis $(n=2)$. Chest radiographs and computer tomographic imaging detected bilateral pleural effusions $(n=4)$, bilateral interstitial infiltrates $(n=4)$, or bilateral pulmonary nodules $(n=$ 2). The duration of illness lasted from 3 weeks to 6 years, with a median of 6 months. One patient had chronic renal failure, noted at admission, caused by hypertensive nephropathy. The patients were treated with corticosteroids $(n=4)$, antibiotics $(n=$ $3)$, or bronchodilators $(n=1)$.

The ANCA, other serological tests, histopathological findings, final clinical diagnoses, and follow-up data are summarized in Table 1. By ANCA-IIF testing, four patients were C-ANCA+ and four patients were P-ANCA+. The titers ranged from 1:40 to 1280 . ELISA-ANCA was performed in two patients: one patient was borderline for PR-3 (Patient 1, 12 units; negative $\leq 10$ ELISA units) and another was negative for PR-3 and myeloperoxidase (Patient 4).

Four patients had multiple autoantibodies present in their sera at the time of a positive ANCA: antinuclear antibodies (ANA; $n=2$ ), rheumatoid factor $(n=2)$, anti-DNA ( $n=2)$, anti-smooth muscle antibody $(n=1)$, and lupus anticoagulant $(n=$ 1). All of these other autoantibodies were not considered to be atypical, aberrant, or variant ANCA.

The open-lung biopsies showed various patterns of tissue injury (Table 1). The most common histological pattern was a nonspecific interstitial pneumonia (NSIP; $n=4$ ) associated with ill-defined granulomas (Patient 3; Fig. 1), fibrosis (Patient 6; Fig. 2), acute fibrinous pleuritis (Patient 7; Fig. 3), or eosinophilia. Bronchiolitis obliterans organizing pneumonia (BOOP) was the dominant pattern in Patient 4 (Fig. 4) and coexisted with NSIP in Patient 5. Other histological patterns of lung injury in the remaining patients included diffuse alveolar damage (DAD; Patient 1), organizing alveolar hemorrhage without capillaritis (Patient 2), and necrotic granulomas (Patient 8).

The final diagnosis correlated the pathologic findings with the subsequent clinical course. Five patients had a rheumatologic disorder with pulmonary involvement: systemic lupus erythematosus (Patient 7), rheumatoid lung (Patient 5), dermatomyositis (Patient 1), probable antiphospholipid antibody syndrome (Patient 2), and an unclassified connective tissue disorder (Patient 6). The remaining patients were diagnosed with chronic hypersensitivity pneumonia (Patient 3), postinfectious bronchitis/bronchiectasis (Patient 4), and ulcerative colitis-related granulomatous lung disease (Patient 8).

In follow-up evaluations, none of the patients have developed renal disease or systemic vasculitis. No specific antigen was identified in Patient 3 with chronic hypersensitivity pneumonia. The necrotizing granulomas identified in Patient 8 were thought to be a manifestation of her underlying inflammatory bowel disease. Four patients are alive and well with resolution of their pulmonary disease, but four patients have died, three deaths of which could be directly attributed to lung disease. 


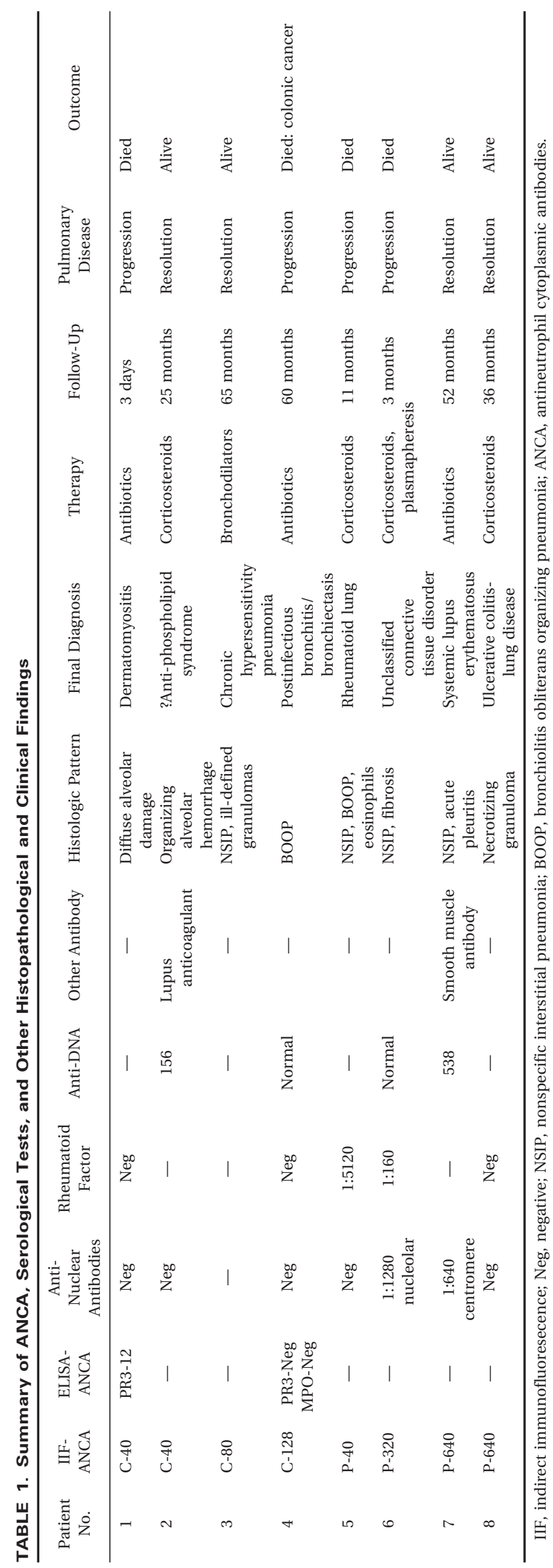

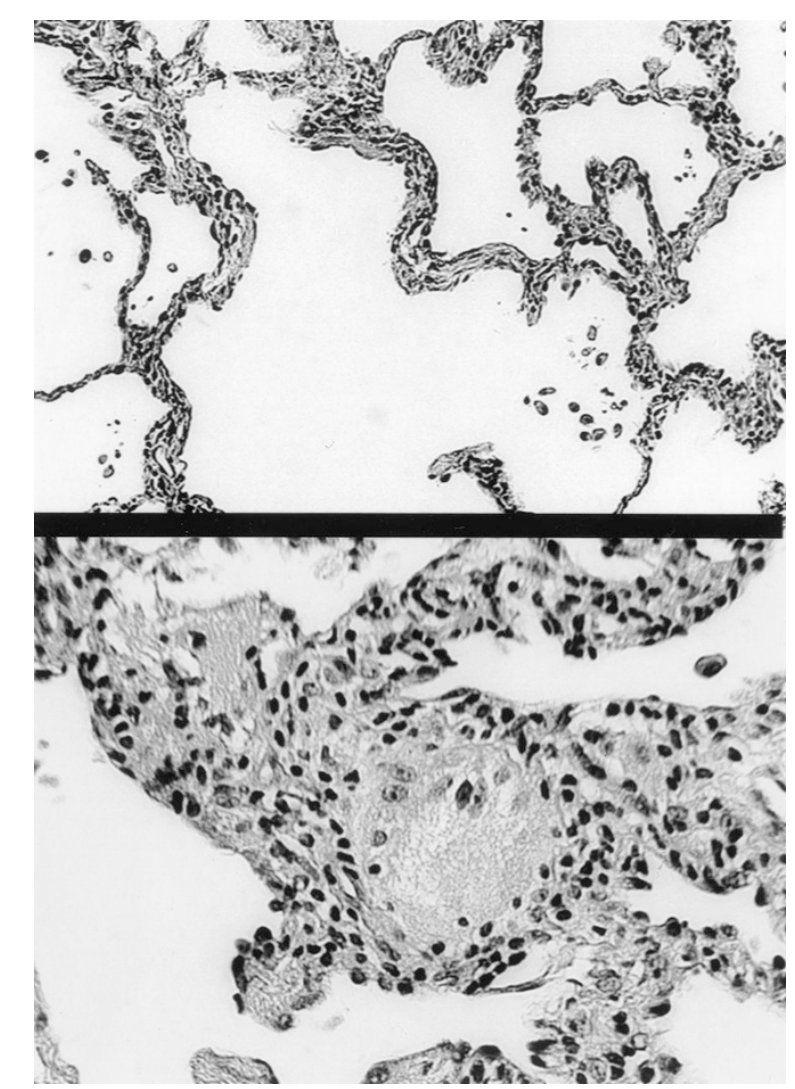

FIGURE 1. Cytoplasmic antineutrophil cytoplasmic antibodies 1-80: Nonspecific interstitial pneumonia (top) associated with ill-defined granulomata (bottom). Final diagnosis: chronic hypersensitivity pneumonia. Patient 3.

\section{DISCUSSION}

In the beginning of our study, we considered that the lung biopsy findings represented unusual manifestations of ANCA-related lung disease. This was understandable, given the broad spectrum of "typical" and "atypical" histological lung injury patterns that may occur in WG or MPA (Table $2 ; 17-30$ ). Some of these "atypical" patterns (i.e., NSIP, BOOP, $\mathrm{DAD}$, or pleuritis) overlapped with the findings that were seen in our patients, but no vasculitic changes were evident. Only after correlating the histopathological results with the clinical, radiographic, serological, and other laboratory data were we assured that none of our patients had WG or MPA.

Although ANCA have become useful serological markers for diagnosis and monitoring of WG and MPA, they can be present in other diseases. In 1989, DeClerck et al. (31) reported a C-ANCA+ patient with active pulmonary tuberculosis who had been misdiagnosed with limited WG. Davenport (12) presented four patients with nonvasculitic diseases who had false-positive ANCA. A review of the literature reveals that ANCA may occur in various clinical settings unrelated to WG or MPA (Table 3; 3-5, $11,13,14,32-80)$. Many of these diseases have 


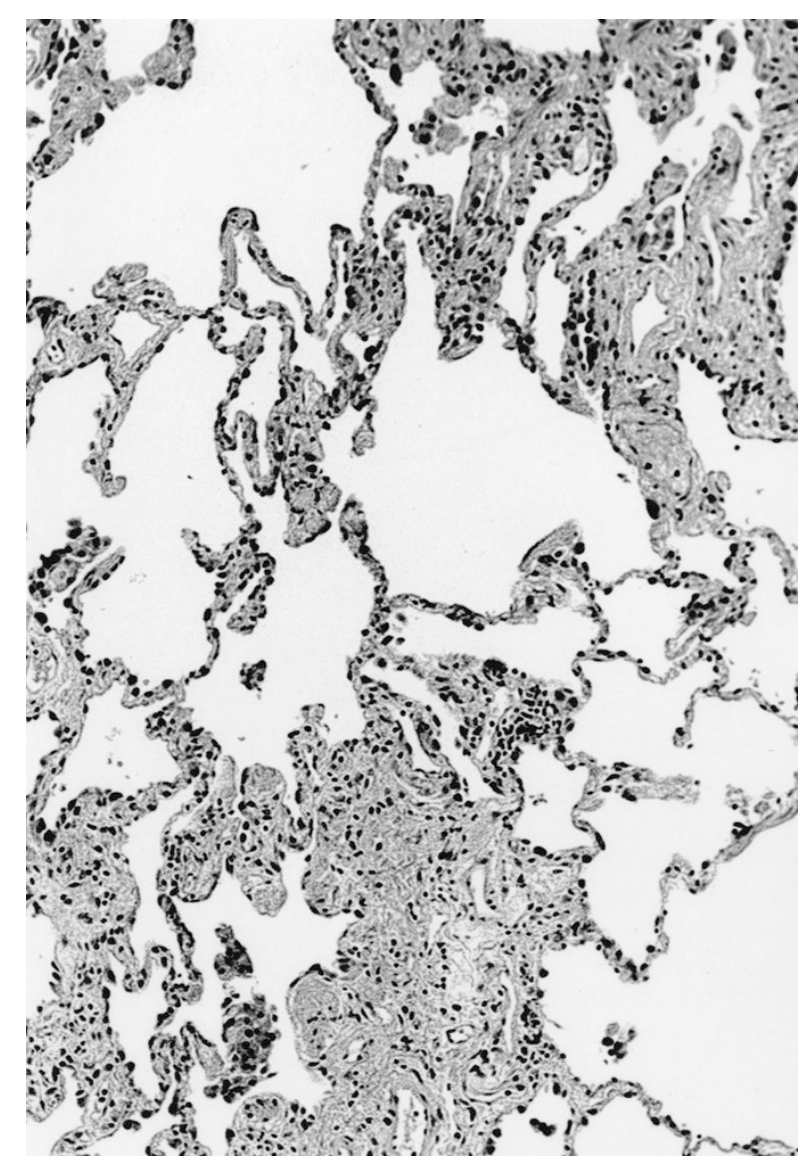

FIGURE 2. Perinuclear antineutrophil cytoplasmic antibodies $1-320$ : Nonspecific interstitial pneumonia with focal fibrosis. Final diagnosis: unclassified connective tissue disorder. Patient 6.

clinical presentations that can closely resemble systemic vasculitis $(33,34)$.

There are several reasons that ANCA occur in other disorders. Although PR-3 and myeloperoxidase are the most frequent determinants, ANCA can be directed to lactoferrin, enolase, cathepsin-G, elastase, lysozyme, and other antigens $(3-5,11,81-$ 83). Some patients with connective tissue disorders have an atypical ANCA in which the IIF staining pattern does not resemble typical C- or P-ANCA $(11,82)$. By IIF, P-ANCA may be identified in patients with systemic lupus erythematosus and may be difficult to distinguish from ANA $(2,3,15,35,36$, 83). P-ANCA can be seen in various connective tissue diseases, such as in rheumatoid arthritis, inflammatory arthritis, progressive systemic sclerosis, and other disorders $(4,33,38,84)$. In rheumatoid arthritis, granulocyte-specific ANA can closely resemble P-ANCA in IIF tests $(3,5,38,82)$. Finally, novel or uncharacterized antibodies could conceivably give rise to ANCA.

Interpretative and reproducibility issues may occur in the evaluation of sera by the IIF method (33, $82,83)$. There may be considerable interinstitutional variation in performing ANCA $(4,9,85)$.

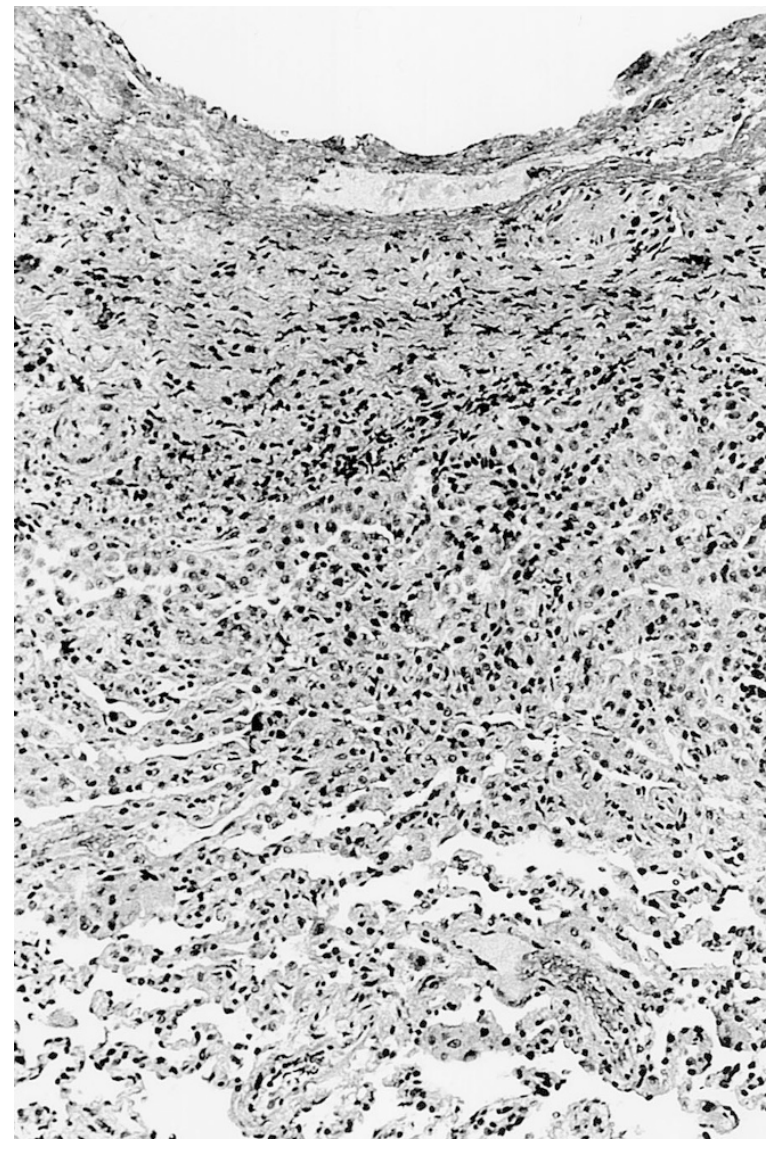

FIGURE 3. Cytoplasmic antineutrophil cytoplasmic antibodies 1-640: Nonspecific interstitial pneumonia with acute fibrinous pleuritis. Final diagnosis: systemic lupus erythematosus. Patient 7.

Among various commercial assay kits for ANCA, Lim et al. (86) showed that the INOVA IIF kit, which was used in our study, had a sensitivity of $91 \%$ but a specificity of $61 \%$. This low specificity approximates our finding that $30 \%(8 / 27)$ of those ANCA positive did not have WG or MPA but another disorder. There can be differences in technologist test performance and interpretation of IIF-ANCA tests, based on individual ability and experience $(9,33$, 83). A lack of standardized reporting of ANCA results by some laboratories further complicates this situation.

In a literature review and meta-analysis of the utility of ANCA testing in WG, Rao et al. (87) found that the sensitivity of ANCA is higher in active disease $(91 \%)$ than in inactive disease $(63 \%)$ but that the specificity was similar $(98.6 \%$ versus $99.5 \%$, respectively). However, in low-prevalence situations, such as when ANCA is not expected, a substantial number of false-positive tests occurs. These authors recommended "judicious ordering of C-ANCA testing and cautious interpretation of the test results (87)."

For surgical pathologists, the implications of our study are clear. ANCA positivity alone, in the absence of appropriate clinical and pathologic find- 


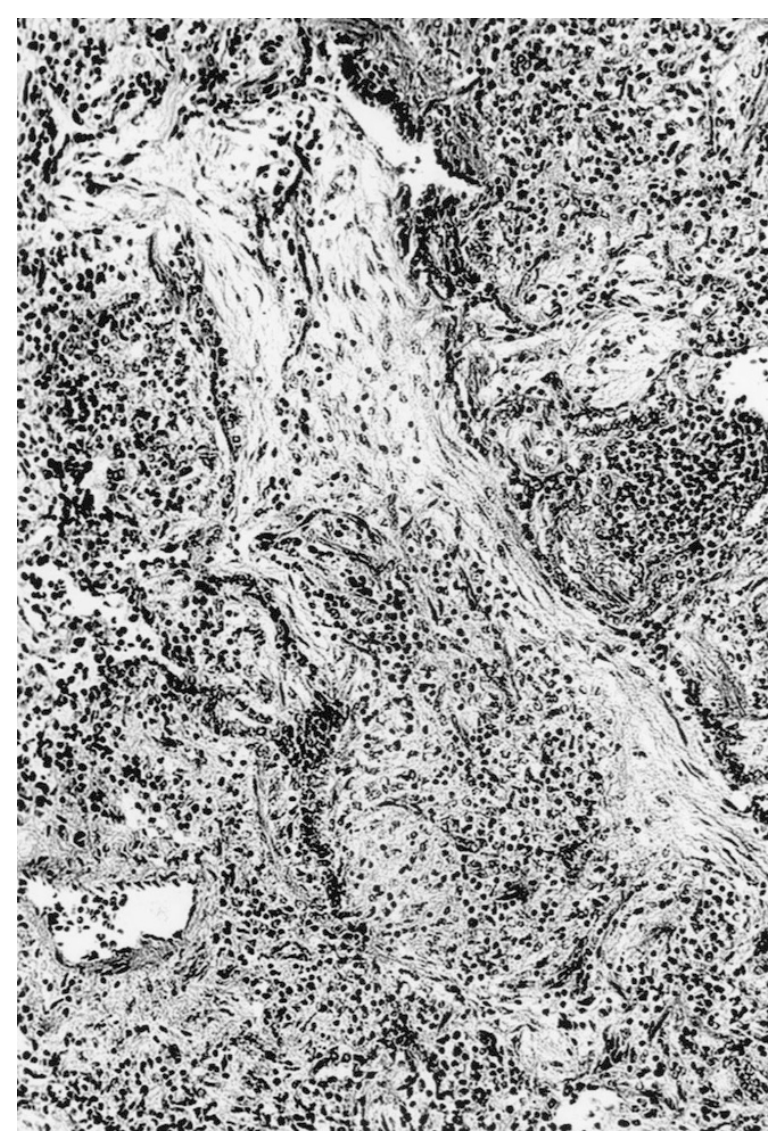

FIGURE 4. Cytoplasmic antineutrophil cytoplasmic antibodies 1-1280: Bronchiolitis obliterans organizing pneumonia. Final diagnosis: postinfectious bronchitis/bronchiectasis. Patient 4.

TABLE 2. Atypical Histological Patterns in Wegener's Granulomatosis and Microscopic Polyarteritis

Eosinophilia (18, 19, 21, 27-29)

Bronchiolitis obliterans organizing pneumonia (21-23, 26-29)

Acute or chronic bronchiolitis (21)

Bronchocentric injury $(18,21-23,26,27,29)$

Bronchopneumonia (21)

Follicular bronchiolitis (21)

Bronchial stenosis $(21,29)$

Squamous metaplasia (21)

Organizing pneumonia (18)

Interstitial fibrosis $(20,21,26,29)$

Fibrous scar $(17,18,21)$

Lymphoid aggregates $(18,21)$

Diffuse alveolar damage $(26,29)$

Lipoid pneumonia $(21,23,29)$

Xanthogranulomatous lesions $(21,23)$

Acute fibrinous pleuritis $(18,21,23,26)$

Chronic fibrosing pleuritis $(18,21,26)$

ings, should not influence the pathologist to render a diagnosis of WG or MPA. In the setting of a positive ANCA, caution should be exerted when a lung biopsy does not show necrotizing granulomatous inflammation and vasculitis or alveolar hemorrhage with/or without capillaritis. When another pattern of injury such as NSIP, BOOP, or pleuritis predominates, there must be a careful search for subtle histological features of WG or MPA. For example, a
TABLE 3. Other Disorders that May Be Associated with Antineutrophil Cytoplasmic Antibodies

Connective tissue disorders

Systemic lupus erythematosus $(2,35,36)$

Rheumatoid arthritis $(37,38)$

Felty's syndrome (39)

Progressive systemic sclerosis $(38,40)$

Sjogren's syndrome $(41,42)$

Ankylosing spondylitis (43)

Reactive arthritis (43)

Juvenile rheumatoid arthritis (44)

Takayasu's vasculitis $(6,7)$

Dermatomyositis (33)

Antiphospholipid syndrome (33)

Gastrointestinal disorders

Ulcerative colitis $(45-47)$

Crohn's disease (45-47)

Sclerosing cholangitis $(45,47)$

Autoimmune liver disorders $(47,48)$

Primary billary cirrhosis (48)

Other disorders

Idiopathic necrotizing and crescentic glomerulonephritis (2)

Churg-Strauss syndrome (34, 49, 50)

Goodpasture's disease $(51,52)$

Post-streptococcal glomerulonephritis (53)

Giant cell arteritis (54)

Kawasaki's disease (55)

Sarcoidosis (56)

Sweet's syndrome (57)

Classic polyartertitis nodosa (49)

Infections

Mycobacterial (12, 31, 58)

Leprosy (59)

Aspergillus (60)

Sporotrichosis (61)

Paracocciodomycosis (62)

Chromomycosis (63)

Amoebiasis (64)

Subacute bacterial endocarditis (65)

Malaria (58)

Leptospirosis (66)

Influenza virus (67)

Human immunodeficiency virus/AIDS (12, 68-70)

Cystic fibrosis (71)

Bacterial septicemia (72)

Other pulmonary infections $(13,61,72)$

Neoplasia

Lymphoid neoplasia $(12,73)$

Lymphomatoid granulomatosis $(6,7)$

Monoclonal gamopathies (73, 74)

Myeloproliferative disorders $(73,75)$

Carcinomas (76)

Miscellaneous

Bone marrow transplantation (77)

Hemodialysis (78)

Drugs (79)

Anticytokeratins (80)

small focus of vasculitis or capillaritis could be overlooked when another pattern predominates. Although many hospital laboratories only perform IIF testing, it is highly recommended that a positive ANCA result be followed by an ELISA for PR-3 and/or myeloperoxidase $(3,5,11,14,33,82,83,86$, 88). The pathologist should inquire as to what type of ANCA test was performed (IIF versus ELISA), where it was performed (hospital versus reference versus research laboratory), and whether multiple autoantibodies (antinuclear antibodies, rheumatoid factor, antiglomerular basement membrane 
antibody, or others) are present. Finally, the results of ANCA testing must always be viewed in the context of the clinical picture, with correlation of the histological findings with clinical, radiographic, and other serological tests $(24,87)$. An inappropriate diagnosis based solely on the results of ANCA testing could have serious consequences, particularly if the patient is unnecessarily treated with glucocorticoids and cytotoxic agents.

Acknowledgments: The authors wish to thank Dr. Carlos Agudelo for reviewing the manuscript, Tammy Davis, M.T. (A.S.C.P.) for assistance in reviewing the ANCA data, and Robert Santoianni for his photographic expertise.

\section{REFERENCES}

1. Davies DJ, Moran JE, Niall JF, Ryan GB. Segmental necrotising glomerulonephritis with antineutrophil antibody: possible arbovirus aetiology? Br Med J 1982;285:606.

2. Falk RJ, Jennette JC. Anti-neutrophil cytoplasmic autoantibodies with specificity for myeloperoxidase in patients with systemic vasculitis and idiopathic necrotizing and crescentic glomerulonephritis. N Engl J Med 1988;318:1651-7.

3. Kallenberg CG, Mulder AH, Cohen Tervaert JW. Antineutrophil cytoplasmic antibodies: a still-growing class of autoantibodies in inflammatory disorders. Am J Med 1992;93:67582.

4. Hoffman GS, Specks U. Antineutrophil cytoplasmic antibodies. Arthritis Rheum 1998;41:1521-37.

5. Savige J, Davies D, Falk RJ, Jennette JC, Wiik A. Antineutrophil cytoplasmic antibodies and associated diseases: a review of the clinical and laboratory features. Kidney Int 2000; $57: 846-62$.

6. Cohen Tervaert JW, van der Woude FJ, Fauci AS, Ambrus JL, Velosa J, et al. Association between active Wegener's granulomatosis and anticytoplasmic antibodies. Arch Intern Med 1989;149:2461-5.

7. Kerr GS, Fleisher TA, Hallahan CW, Leavitt RY, Fauci AS, Hoffman GS. Limited prognostic value of changes in antineutrophil cytoplasmic antibody titer in patients with Wegener's granulomatosis. Arthritis Rheum 1993;36:365-71.

8. Goldschmeding R, Cohen Tervaert JW, Gans RO, Dolman $\mathrm{KM}$, van den Ende ME, Kuizinga MC, et al. Different immunological specificities and disease associations of c-ANCA and p-ANCA. Neth J Med 1990;36:114-6.

9. Niles JL, McCluskey RT, Ahmad MF, Arnaout MA. Wegener's granulomatosis autoantigen is a novel neutrophil serine proteinase. Blood 1989;74:1888-93.

10. Goldschmeding R, van der Schoot CE, ten Bokkel Huinink D, Hack CE, van den Ende ME, Kallenberg CG, et al. Wegener's granulomatosis autoantibodies identify a novel diisopropylfluorophosphate-binding protein in the lysosomes of normal human neutrophils. J Clin Invest 1989;84: 1577-87.

11. Bajema IM, Hagen EC. Evolving concepts about the role of antineutrophil cytoplasm autoantibodies in systemic vasculitides. Curr Opin Rheumatol 1999;11:34-40.

12. Davenport A. "False positive" perinuclear and cytoplasmic anti-neutrophil cytoplasmic antibody results leading to misdiagnosis of Wegener's granulomatosis and/or microscopic polyarteritis. Clin Nephrol 1992;37:124-30.

13. Davenport A, Lock RJ, Wallington TB. Clinical relevance of testing for antineutrophil cytoplasm antibodies (ANCA) with a standard indirect immunofluorescence ANCA test in patients with upper or lower respiratory tract symptoms. Tho$\operatorname{rax} 1994 ; 49: 213-7$.

14. Stone JH, Talor M, Stebbing, Uhlfelder ML, Rose NR, Carson, $\mathrm{KA}$, et al. Test characteristics of immunofluorescence and ELISA tests in 856 consecutive pateints with possible ANCAassociatied conditions. Arthritis Care Res 2001;13:424-34.

15. Lee SS, Lawton JW, Chak W. Distinction between antinuclear antibody and P-ANCA. J Clin Pathol 1991;44:962-3.

16. Jennette JC, Falk RJ, Andrassy K, Bacon PA, Chung J, Gross $\mathrm{WL}$, et al. Nomenclature of systemic vasculitides. Proposal of an international consensus conference. Arthritis Rheum 1994;37:187-92.

17. Yoshikawa Y, Watanabe T. Pulmonary lesions in Wegener's granulomatosis: a clinicopathologic study of 22 autopsy cases. Hum Pathol 1986;17:401-10.

18. Mark EJ, Matsubara O, Tan-Liu NS, Fienberg R. The pulmonary biopsy in the early diagnosis of Wegener's (pathergic) granulomatosis: a study based on 35 open lung biopsies. Hum Pathol 1988;19:1065-71.

19. Yousem SA, Lombard CM. The eosinophilic variant of Wegener's granulomatosis. Hum Pathol 1988;19:682-8.

20. Nada AK, Torres VE, Ryu JH, Lie JT, Holley KE. Pulmonary fibrosis as an unusual clinical manifestation of a pulmonaryrenal vasculitis in elderly patients. Mayo Clin Proc 1990;65: 847-56.

21. Travis WD, Hoffman GS, Leavitt RY, Pass HI, Fauci AS. Surgical pathology of the lung in Wegener's granulomatosis. Review of 87 open lung biopsies from 67 patients. Am J Surg Pathol 1991;15:315-33.

22. Yousem SA. Bronchocentric injury in Wegener's granulomatosis: a report of five cases. Hum Pathol 1991;22:535-40.

23. Galateau F, Loire R, Capron F, Delajartre AY, Brambilla E, Bejvi-Thivolet F, et al. Pulmonary lesions in Wegener's disease. Report of the French anatomo-clinical research group. Study of 40 pulmonary biopsies. Rev Mal Respir 1992;9:43142.

24. Colby TV, Specks U. Wegener's granulomatosis in the 1990s - a pulmonary pathologist's perspective. In: Churg A, Katzenstein ALA, editors. The lung: current concepts. Baltimore: Williams and Wilkins; 1993. p. 195-218.

25. Travis WD. Common and uncommon manifestations of Wegener's granulomatosis. Cardiovasc Pathol 1994;3:217-25.

26. Gaudin PB, Askin FB, Falk RJ, Jennette JC. The pathologic spectrum of pulmonary lesions in patients with antineutrophil cytoplasmic autoantibodies specific for antiproteinase 3 and anti-myeloperoxidase. Am J Clin Pathol 1995;104:7-16.

27. Katzenstein AL, Locke WK. Solitary lung lesions in Wegener's granulomatosis. Pathologic findings and clinical significance in 25 cases. Am J Surg Pathol 1995;19:545-52.

28. Uner AH, Rozum-Slota B, Katzenstein AL. Bronchiolitis obliterans-organizing pneumonia (BOOP)-like variant of Wegener's granulomatosis. A clinicopathologic study of 16 cases. Am J Surg Pathol 1996;20:794-801.

29. Mark EJ, Flieder DB, Matsubara O. Treated Wegener's granulomatosis: distinctive pathological findings in the lungs of 20 patients and what they tell us about the natural history of the disease. Hum Pathol 1997;28:450-8.

30. Colby TV. Pulmonary pathology in patients with systemic autoimmune diseases. Clin Chest Med 1998;19:587-612.

31. De Clerck LS, Van Offel JF, Smolders WA, Empsten FA, Bridts $\mathrm{CH}$, Bourgeois N, et al. Pitfalls with anti-neutrophil cytoplasmic antibodies (ANCA). Clin Rheumatol 1989;8:512-6.

32. Peter HH, Metzger D, Rump A, Rother E. ANCA in diseases other than systemic vasculitis. Clin Exp Immunol 1993;(93 Suppl 1):12-4.

33. Merkel PA, Polisson RP, Chang Y, Skates SJ, Niles JL. Prevalence of antineutrophil cytoplasmic antibodies in a large 
inception cohort of patients with connective tissue disease. Ann Intern Med 1997;126:866-73.

34. Conron M, Beynon HLC. Churg-Strauss syndrome. Thorax 2000;55:870-7.

35. Schnabel A, Csernok E, Isenberg DA, Mrowka C, Gross WL. Antineutrophil cytoplasmic antibodies in systemic lupus erythematosus. Prevalence, specificities, and clinical significance. Arthritis Rheum 1995;38:633-7.

36. Chin HJ, Ahn C, Lim CS, Chung HK, Lee JG, Song YW, et al. Clinical implications of antineutrophil cytoplasmic antibody test in lupus nephritis. Am J Nephrol 2000;20:57-63.

37. Mulder AH, Horst G, van Leeuwen MA, Limburg PC, Kallenberg CG. Antineutrophil cytoplasmic antibodies in rheumatoid arthritis. Characterization and clinical correlations. Arthritis Rheum 1993;36:1054-60.

38. Bosch X, Llena J, Collado A, Font J, Mirapeix E, Ingelmo M, et al. Occurrence of antineutrophil cytoplasmic and antineutrophil (peri)nuclear antibodies in rheumatoid arthritis. J Rheumatol 1995;22:2038-45.

39. Juby A, Johnston C, Davis P, Russell AS. Antinuclear and antineutrophil cytoplasmic antibodies (ANCA) in the sera of patients with Felty's syndrome. Br J Rheumatol 1992;31: $185-8$.

40. Katrib A, Sturgess A, Bertouch JV. Systemic sclerosis and antineutrophil cytoplasmic autoantibody-associated renal failure. Rheumatol Int 1999;19:61-3.

41. Font J, Ramos-Casals M, Cervera R, Bosch X, Mirapeix E, Garcia-Carrasco M, et al. Antineutrophil cytoplasmic antibodies in primary Sjogren's syndrome: prevalence and clinical significance. Br J Rheumatol 1998;37:1287-91.

42. Nishiya K, Chikazawa H, Hashimoto K, Miyawaki S. Antineutrophil cytoplasmic antibody in patients with primary Sjogren's syndrome. Clin Rheumatol 1999;18:268-71.

43. Locht H, Skogh T, Kihlstrom E. Anti-lactoferrin antibodies and other types of anti-neutrophil cytoplasmic antibodies (ANCA) in reactive arthritis and ankylosing spondylitis. Clin Exp Immunol 1999;117:568-73.

44. Mulder L, van Rossum M, Horst G, Limburg P, de GraeffMeeder Er, Kuis W, et al. Antineutrophil cytoplasmic antibodies in juvenile chronic arthritis. J Rheumatol 1997;24: 568-75.

45. Snook JA, Chapman RW, Fleming K, Jewell DP. Antineutrophil nuclear antibody in ulcerative colitis, Crohn's disease and primary sclerosing cholangitis. Clin Exp Immunol 1989;76:30-3.

46. Saxon A, Shanahan F, Landers C, Ganz T, Targan S. A distinct subset of antineutrophil cytoplasmic antibodies is associated with inflammatory bowel disease. J Allergy Clin Immunol 1990;86:202-10.

47. Hardarson S, Labrecque DR, Mitros FA, Neil GA, Goeken JA. Antineutrophil cytoplasmic antibody in inflammatory bowel and hepatobiliary diseases. High prevalence in ulcerative colitis, primary sclerosing cholangitis, and autoimmune hepatitis. Am J Clin Pathol 1993;99:277-81.

48. Roozendaal C, Kallenberg CG. Anti-neutrophil cytoplasm autoantibodies (ANCA) in autoimmune liver diseases. Hepatogastroenterology 1999;46:3034-40.

49. Cohen P, Guillevin L, Baril L, Lhote F, Noel LH, Lesavre P. Persistence of antineutrophil cytoplasmic antibodies (ANCA) in asymptomatic patients with systemic polyarteritis nodosa or Churg-Strauss syndrome: follow-up of 53 patients. Clin Exp Rheumatol 1995;13:193-8.

50. Guillevin L, Cohen P, Gayraud M, Lhote F, Jarrousse B, Casassus P. Churg-Strauss syndrome. Clinical study and long-term follow-up of 96 patients. Medicine (Baltimore) 1999;78:26-37.

51. Bosch X, Mirapeix E, Font J, Borrellas X, Rodriguez R, LopezSoto A, et al. Prognostic implication of anti-neutrophil cytoplasmic autoantibodies with myeloperoxidase specificity in anti-glomerular basement membrane disease. Clin Nephrol 1991;36:107-13.

52. Bonsib SM, Goeken JA, Kemp JD, Chandran P, Shadur C, Wilson L. Coexistent anti-neutrophil cytoplasmic antibody and antiglomerular basement membrane antibody associated disease-report of six cases. Mod Pathol 1993;6:526-30.

53. Ardiles LG, Valderrama G, Moya P, Mezzano SA. Incidence and studies on antigenic specificities of antineutrophilcytoplasmic autoantibodies (ANCA) in poststreptococcal glomerulonephritis. Clin Nephrol 1997;47:1-5.

54. McHugh NJ, James IE, Plant GT. Anticardiolipin and antineutrophil antibodies in giant cell arteritis. J Rheumatol 1990;17:916-22.

55. Savage CO, Tizard J, Jayne D, Lockwood CM, Dillon MJ. Antineutrophil cytoplasm antibodies in Kawasaki disease. Arch Dis Child 1989;64:360-3.

56. Forde AM, Feighery C, Jackson J. Anti-monocyte cytoplasmic antibodies in granulomatous disease. Clin Immunol Immunopathol 1996;81:88-95.

57. Kemmett D, Harrison DJ, Hunter JA. Antibodies to neutrophil cytoplasmic antigens: serologic marker for Sweet's syndrome. J Am Acad Dermatol 1991;24:967-9.

58. Adebajo AO, Charles P, Maini RN, Hazleman BL. Autoantibodies in malaria, tuberculosis and hepatitis B in a West African population. Clin Exp Immunol 1993;92:73-6.

59. Medina F, Camargo A, Moreno J, Zonana-Nacach A, AcevesAvila J, Fraga A. Anti-neutrophil cytoplasmic autoantibodies in leprosy. Br J Rheumatol 1998;37:270-3.

60. Cho C, Asuncion A, Tatum AH. False-positive antineutrophil cytoplasmic antibody in aspergillosis with oxalosis. Arch Pathol Lab Med 1995;119:558-61.

61. Byrd RP, Hourany J, Cooper C, Roy TM. False-positive antineutrophil cytoplasmic antibodies in a patient with cavitary pulmonary sporotrichosis. Am J Med 1998;104:101-3.

62. Stappaerts I, Bogers J, Ebo D, Vanden Broecke E, Stevens WJ, Vermeire P. C-ANCA positivity in a Belgian patient with pulmonary paracoccidioidomycosis. Eur Respir J 1997;10: 2419-22.

63. Galperin C, Shoenfeld Y, Gilburd B, Esterre P, Meroni PL, Del Papa N, et al. Anti-neutrophil cytoplasmic antibodies in patients with chromomycosis. Clin Exp Rheumatol 1996;14: 479-83.

64. Pudifin DJ, Duursma J, Gathiram V, Jackson TF. Invasive amoebiasis is associated with the development of anti-neutrophil cytoplasmic antibody. Clin Exp Immunol 1994;97:48-51.

65. Choi HK, Lamprecht P, Niles JL, Gross WL, Merkel PA. Subacute bacterial endocarditis with positive cytoplasmic antineutrophil cytoplasmic antibodies and anti-proteinase 3 antibodies. Arthritis Rheum 2000;43:226-31.

66. Constantin A, Marin F, Oksman F, Bouteiller G. Antineutrophil cytoplasmic antibodies in leptospirosis. J Rheumatol 1996;23:41.

67. Staud R, Ramos LG. Influenza A-associated bronchiolitis obliterans organizing pneumonia mimicking Wegener's granulomatosis. Rheumatol Int 2001;20:125-8.

68. Klaassen RJ, Goldschmeding R, Dolman KM, Vlekke AB, Weigel HM, Eeftinck Schattenkerk JK, et al. Anti-neutrophil cytoplasmic autoantibodies in patients with symptomatic HIV infection. Clin Exp Immunol 1992;87:24-30.

69. Savige JA, Chang L, Horn S, Crowe SM. Anti-nuclear, antineutrophil cytoplasmic and anti-glomerular basement membrane antibodies in HIV-infected individuals. Autoimmunity 1994;18:205-11.

70. Cornely OA, Hauschild S, Weise C, Csernok E, Gross WL, Salzberger B, et al. Seroprevalence and disease association of antineutrophil cytoplasmic autoantibodies and antigens in HIV infection. Infection 1999;27:92-6.

71. Sediva A, Bartunkova J, Kolarova I, Hrusak O, Vavrova V, Macek M Jr, et al. Antineutrophil cytoplasmic autoantibod- 
ies (ANCA) in children with cystic fibrosis. J Autoimmun 1998;11:185-90.

72. Mege JL, Escallier JC, Capo C, Bongrand P, Velut JG, Quiles N, Soubeyrand J, Durand JM. Anti-neutrophil cytoplasmic antibodies (ANCA) and infection. Adv Exp Med Biol 1993; 336:353-6.

73. Hamidou MA, Derenne S, Audrain MA, Berthelot JM, Boumalassa A, Grolleau JY. Prevalence of rheumatic manifestations and antineutrophil cytoplasmic antibodies in haematological malignancies. A prospective study. Rheumatology (Oxf) 2000;39:417-20.

74. Esnault VL, Jayne DR, Keogan MT, Brownlee AA, Testa A, Lecarrer D, et al. Anti-neutrophil cytoplasm antibodies in patients with monoclonal gammopathies. J Clin Lab Immunol 1990;32:153-9.

75. Savige JA, Chang L, Smith CL, Duggan JC. Anti-neutrophil cytoplasmic antibodies (ANCA) in myelodysplasia and other haematological disorders. Aust N Z J Med 1994;24:282-7.

76. Edgar JD, Rooney DP, McNamee P, McNeill TA. An association between ANCA positive renal disease and malignancy. Clin Nephrol 1993;40:22-5.

77. Martin SJ, Audrain MA, Oksman F, Ecoiffier M, Attal M, Milpied N, et al. Antineutrophil cytoplasmic antibodies (ANCA) in chronic graft-versus-host disease after allogeneic bone marrow transplantation. Bone Marrow Transplant 1997;20:45-8.

78. Weidemann S, Andrassy K, Ritz E. ANCA in haemodialysis patients. Nephrol Dial Transplant 1993;8:839-45.

79. Choi HK, Merkel PA, Walker AM, Niles JL. Drug-associated antineutrophil cytoplasmic antibody-positive vasculitis: prevalence among patients with high titers of antimyeloperoxidase antibodies. Arthritis Rheum 2000;43:405-13.

80. Streicher J, Fabian B, Herkner K, Pointner H, Bayer PM. Anticytokeratins are a potential source of false-positive in- direct immunofluorescence assays for C-ANCA. J Clin Lab Anal 1998;12:54-9.

81. Savige JA, Paspaliaris B, Silvestrini R, Davies D, Nikoloutsopoulos T, Sturgess A, et al. A review of immunofluorescent patterns associated with antineutrophil cytoplasmic antibodies (ANCA) and their differentiation from other antibodies. J Clin Pathol 1998;51:568-75.

82. Savige J, Gillis D, Benson E, Davies D, Esnault V, Falk RJ, et $a l$. International consensus statement on testing and reporting of antineutrophil cytoplasmic antibodies (ANCA). Am J Clin Pathol 1999;111:507-13.

83. Ahmed AEE, Aziz DC. Antineutrophil cytoplasmic antibodies: an update on clinical utility. J Clin Rheumatol 1999;5:151-6.

84. Helsloot J, Virgo S, McGuigan L, Sturgess A. Antineutrophil cytoplasmic antibodies in inflammatory arthritis-potential for misdiagnosis? Br J Rheumatol 1995;34:820-4.

85. Hagen EC, Daha MR, Hermans J, Andrassy K, Csernok E, Gaskin G, et al. Diagnostic value of standardized assays for anti-neutrophil cytoplasmic antibodies in idiopathic systemic vasculitis. Kidney Int 1998;53:743-53.

86. Lim LC, Taylor JG, Schmitz JL, Folds JD, Wilkman AS, Falk RJ, et al. Diagnostic usefulness of antineutrophil cytoplasmic autoantibody serology. Comparative evaluation of commercial indirect fluorescent antibody kits and enzyme immunoassay kits. Am J Clin Pathol 1999;111:363-9.

87. Rao JK, Weinberger M, Oddone EZ, Allen NB, Landsman P, Feussner JR. The role of antineutrophil cytoplasmic antibody (c-ANCA) testing in the diagnosis of Wegener granulomatosis. A literature review and meta-analysis. Ann Intern Med 1995; 123:925-32.

88. Harris A, Chang G, Vadas M, Gillis D. ELISA is the superior method for detecting antineutrophil cytoplasmic antibodies in the diagnosis of systemic necrotising vasculitis. J Clin Pathol 1999;52:670-6. 